\title{
Preparation and evaluation of burns wound healing ointment base of leaves and stem bark of Anthocleista djalonensis (L) extract using animal model.
}

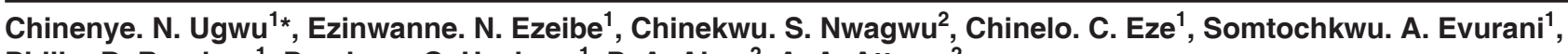
Philip. D. Berebon ${ }^{1}$, Precious. O. Uzoigwe ${ }^{1}$, P. A. Akpa ${ }^{2}$, A. A. Attama ${ }^{2}$

\begin{abstract}
Abstract: This study is aimed at evaluating and comparing the wound healing potential of ointment base of leaves and Stem bark of Anthocleista djalonensis on burn wounds created on wistar albino rats. The leaves and Stem bark of Anthocleista djalonensis collected were extracted using $95 \% \mathrm{v} / \mathrm{v}$ methanol and phytochemical analysis conducted. Simple ointments of varying concentrations were formulated to screen for wound healing activity using the burn wound model on experimental rats grouped into six $(n=4)$. Group 1 was treated with silver sulfadiazine cream (positive control), group 2 with ointment base (negative control), group 3 with $1 \%$ stem bark extract ointment, group 4 with $2 \%$ stem bark ointment, group 5 with $1 \%$ leave extract ointment, and group 6 with $2 \%$ leave extract ointment. All animals were anesthetized before the creation of burn wounds. Measurement was taken on day zero and the wound was left untreated for 48 hours in order to allow bacterial colonization before daily treatment of the wound for 16 days. The result of the phytochemical screening revealed that both extract of Anthocleista djalonensis contains flavonoids, tannins and saponins. On day 2, $1 \%$ stem bark, $2 \%$ stem bark and $1 \%$ leaf extract had $16 \%, 15 \%$, and $10 \%$ wound contraction respectively which was higher than the $8.5 \%$ wound contraction of silver sulfadiazine. Also as the concentration of the extract increased, the wound healing effect also increased as seen by the percentage wound contraction on day 16 for all treatment. The findings of the study have shown that methanolic extracts of stem bark and leaf of Anthocleista djalonensis contained bioactive constituents which have burn wound healing activity. The stem bark extract showed better activity when compared with the leaf extract and also the positive control (silver sulfadiazine).
\end{abstract}

Keywords: Anthocleista djalonensis, Burn wounds, Silver sulfadiazine, Wound healing, Wound infections.

How to cite this article: Ugwu, C.N., Ezeibe, E. N., Nwagwu, C.S., Eze, C.C., Evurani, S.A., Berebon, P.D., Uzoigwe, P.O., Akpa, P.A. and Attama, A.A. (2019). Preparation and evaluation of burns wound healing ointment base of leaves and stem bark of Anthocleista djalonensis (L) extract using animal model. Int. J. Pharm. Edu. Res., 1(2):25-32.

${ }^{1}$ Department of Pharmaceutical Microbiology and Biotechnology, University of Nigeria, Nsukka.

${ }^{2}$ Department of Pharmaceutics, University of Nigeria, Nsukka.

Corresponding Author: Chinenye. N. Ugwu, Department of Pharmaceutical Microbiology and Biotechnology, University of Nigeria, Nsukka. Mob: +2348062141815 , Email: chinenye. ugwu@unn.edu.ng

\section{Source of support: Nil}

Conflict Of Interest: The authors declare no conflict of interest.

This research did not receive any specific grant from funding agencies in the public, commercial, or not-for-profit sectors.

\section{INTRODUCTION}

Wounds could be defined as a cut or breakdown in the protective covering of any tissue disrupting its continuity. ${ }^{1}$ It results in physical interference on the skin (tissue), which is a major obstacle to the establishment of infections by bacterial pathogens in internal tissues. This interference breaches the skin's protective function leading to infection and treatment of the wound usually involves preventing infection. ${ }^{2}$ Wound is a common problem in human day to day activities, which may be as a result of physical, chemical, thermal, microbial or immunological insult to the tissue. ${ }^{3}$ There are various classifications of wound; wounds without tissue loss (e.g., in surgery), wounds with tissue loss (e.g. burn wound, incised wound, lacerated wound), wounds caused as a result of trauma, abrasions or as secondary events in chronic ailments (e.g., venous stasis, diabetic ulcers or pressure sores) and iatrogenic wounds such as skin graft donor sites and derma abrasions. ${ }^{4}$ In many African countries, the use of wood, gas, candles, and kerosene as fuels for cooking and the source of light has increased the incidence of burn wounds. ${ }^{5}$ Burns are damages to the skin or other organic tissues caused by extreme heat, ultraviolet radiation, electricity, flame, respiratory damage resulting from smoke inhalation, friction or contact with heated objects, or with chemicals. ${ }^{6}$ Burns results in a long hospital stay and psychological stress in every area of an affected life, leading to increased morbidity and mortality rate. ${ }^{7}$ Generally, burns are categorized as first, second, or third-degree based on their depth, the area of body surface that is burned, the region or part of the body affected, as well as the extent of the burn and its treatment, depends on the severity of the burn. ${ }^{8}$ Treatment options range from dressing and topical ointment for minor burns to immediate medical attention and hospitalization for severe burns. ${ }^{9}$ WHO estimates that burns cause about 180,000 deaths

(c) The Author(s). 2020 Open Access This article is distributed under the terms of the Creative Commons Attribution-NonCommercial-ShareAlike 4.0 International 
every year, particularly among low and middle-income earners of African and South-East Asia regions having about two-third of burn cases. ${ }^{6}$ Every year, over 1,000,000 people are moderately or severely burnt in India and nearly 173,000 in Egypt, Bangladesh, Colombia, and Pakistan. ${ }^{10}$ It has also been reported that burns cause $17 \%$ temporary disability and $18 \%$ permanent disability to children in many African countries. ${ }^{11}$ The United States of America isn't left out in this report of the burn wound, 1.1 million burn cases requiring medical attention are recorded each year, and approximately 50,000 of these cases require hospitalization. ${ }^{12}$ Major Burns involving 25 percent of the total body surface, accounts for 20,000 cases, and approximately 4,500 of these people die. Also, the United States has documented up to 10,000 deaths every year associated with burn-related infections, and only 60 percent survived. ${ }^{13}$

Exposure of burn wound places patients at high risk of infection, ${ }^{14}$ especially drug-resistant infections, ${ }^{15}$ which often results in delayed wound healing, high treatment cost, increased mortality rate, and significantly longer hospital stays. ${ }^{16}$ Wound infections are most common in developing countries because of poor hygienic conditions. ${ }^{17}$ Infection can elicit a pronounced immune response that is accompanied by sepsis or even septic shock resulting in hypotension and impaired perfusion of end organs, including the skin. All of these processes result in delayed wound healing.9 Besides, multi-organ failure and sepsis are the leading causes of death following a severe burn owning to the colonization of burn wound by microorganisms within 2 days. ${ }^{18}$ Microorganisms are ubiquitous in nature, and burn wounds aren't left out. This colonization progresses into an invasion of surrounding adjacent tissues within 5 days followed by degradation. ${ }^{19}$ So prevention and management of infection should be the primary concern in the treatment of burn patients employing accurate and early diagnosis as the first step. ${ }^{20}$

Dynamic processes with overlapping phases are involved in the healing of all wounds. Such phases includes: Haemostasis and inflammatory phase, proliferative phase, then the maturation and remodeling phase. ${ }^{21}$ In the management of burn wounds, their depth is of great importance, first-degree burn affecting only epidermis, second superficial degree affecting epidermis and papillary dermis, second deep degree affecting epidermis and reticular dermis and third-degree or full-thickness that affect the three layers of the skin and muscles but in the world, scald burns represent the most frequent group. ${ }^{22}$ Topical antibiotics adopted in the 60's and 70's (mafenide and silver sulfadiazine) greatly decreased the incidence of mortality associated with burns ${ }^{23}$ hence; the use of topical antibiotics, in the management of all degrees of burn wounds.
Also, in burns management, multiple drug-resistant organisms associated with modern medicines is of great concern and their presence significantly delays wound healing, prolong hospitalization, and increase mortality and treatment costs; this has led researchers into the search for alternative traditional medicines with no undue effects. $^{24}$

Traditional medicines, including plant-derived extracts (phytochemicals) of natural origin, have found usefulness in the treatment of wide varieties of diseases either in combination or indifferently. ${ }^{25}$ Several studies have reported that natural products have a long history of use in wound care, and the belief that they are safer than standard therapies has necessitated a growing interest in the use of natural products. ${ }^{26}$ In many developing countries, higher percentage of patients still use herbal remedies to treat diseases. Its availability, effectiveness, lack of a problem of resistance, and reduced cost has continued to maintain popularity despite the availability of modern medicines. ${ }^{27}$ It has been estimated by the World Health Organisation that at least $80 \%$ of the world population, mainly in developing countries, still depend on herbal medicines for their primary health care needs. ${ }^{28}$ The use of plant remedies has steadily increased worldwide in recent years as well as the search for new phytochemicals that potentially could be developed as useful drugs for the treatment of infectious diseases. ${ }^{29}$ Extensive research has been done on wound healing, and several plants have been found useful in the treatment of skin disorders such as abscesses, acne, burns, boils, incisions, ringworm, rashes, shingles, sores, wounds and warts. $^{30}$

Anthocleista djalonensis, specie of Anthocleista and a shrub-like medicinal plant of the Gentianaceae family is widely distributed in tropical Africa, Madagascar,bn and on Comoros. ${ }^{31}$ Anthocleista djalonensis is commonly known as a cabbage tree and produces fruits during October and November in Nigeria, but names used to describe Anthocleista species are usually derived from the areas or regions of the country in which they are found. In Nigeria, the Yorubas' called it sapo, Hausas' kwarii, okpokolo in Igbo and osuo in Bayelsa (Southern Nigeria). ${ }^{32}$ Anthocleista djalonensis is widely used throughout its distribution area to treat varieties of diseases. ${ }^{33}$ Extracts from different parts of the plant has been used as an antidiabetic, antimalarial, antipyretic, analgesic, antiplasmodial and antibacterial agent to treat inflammation, wounds and sores. ${ }^{34}$ The antibacterial activity and wound healing activity of $A$. djalonensis leave extract has been studied using several wound models but not burns model and also the use of $A$. djalonensis stem bark extract in burn wound healing has not been studied.

This present study was carried out to assess and compare the burn wound healing potential of an 
ointment base containing methanolic extract of leave and stem bark of $A$. djalonensis for topical application on wistar albino rats.

\section{MATERIALS AND METHODS}

\section{Equipment}

Electronic weighing balance, milling machine, flat trays, crucible, stirrer, water bath, cotton wool, hand gloves, towel, sterile blade, rotary flash evaporator.

\section{Chemicals and Reagents}

Methanol, distilled water, white soft paraffin, hydrogen peroxide, silver sulphadiazine cream (Dermazin), cetostearyl alcohol, wool fat, hard paraffin. All other class used were of analytical grade.

\section{Plant Materials}

The leaves and stem barks of Anthocleista djalonensis were collected from Orba in Udenu Local Government Area of Nsukka in Enugu State and authenticated by Mr. A. Ozioko of the Bioresources Development and Conservation Program (BDCP) Laboratory Nsukka in June 2018.

\section{Experimental animals}

A total of 24 healthy Wistar albino rats of either sex and approximately the same age, weighing about $150-250 \mathrm{~g}$ obtained from the animal house of the Department of Pharmacology and Toxicology, University of Nigeria Nsukka were used for the study. They were fed with standard diet and water ad libitum throughout the experimental period. They were housed in polypropylene cages and maintained under standard conditions. They were also allowed 5 days of acclimatization to the environment before the experimental procedure was commenced on them.

\section{METHODOLOGY}

\section{Preparation of Crude Extract}

The fresh leaves and Stem bark of Anthocleista djalonensis each were air-dried for 4 weeks and pulverized into a fine coarse powder using a mechanical milling machine. Exactly $500 \mathrm{~g}$ of each powdered sample was extracted by cold maceration with $95 \% \mathrm{v} / \mathrm{v}$ methanol in an ambercolored bottle for 72 hours, followed by sieving with a muslin cloth and filtered with No 1 Whatman filter paper. Each filtrate was collected and concentrated in vacuo using rotary flash evaporator. After extraction, dried methanol extract of each plant part was transferred into two separate clean containers and stored in the refrigerator at $4^{\circ} \mathrm{C}$ for further use.
Percentage yield of extract $(\%)=\frac{\text { Weight of the extract concentrate }}{\text { Weight of the plant material }} \times 100$

\section{Phytochemical Analysis}

Phytochemical screening of the extracts were carried out according to the procedure described by Harborne et al. ${ }^{35}$ to check for the presence of some phytoconstituents and intensity of the color change observed was used to quantify the phytochemicals.

\section{Test for Alkaloids (Wagner's test)}

A $20 \mathrm{~mL}$ volume of $5 \%$ sulphuric acid in $50 \%$ ethanol was added to $0.5 \mathrm{~g}$ of the sample and heated on a boiling water bath for 10 minutes, cooled and filtered. $2 \mathrm{ml}$ of the filtrate was treated differently with few drops of Wagner's reagent and Picric acid solution (1\%). The presence of alkaloid is indicated by milky precipitate with Wagner's reagent and yellowish precipitate with $1 \%$ picric acid solution.

\section{Test for Reducing Sugar (Fehling's test)}

A $0.1 \mathrm{~g}$ of the extract was shaken vigorously with $5 \mathrm{ml}$ of distilled water and filtered. The filtrate was used for Frothing test:

Frothing test: To $1 \mathrm{~mL}$ portion of the filtrate was added equal volumes of Fehling's solution I and II and boiled on a water bath for a few minutes. A brick-red precipitate indicates the presence of reducing sugar.

\section{Test for Glycosides (Fehling's test)}

A dilute sulphuric acid $(10 \mathrm{ml})$ acid was added to the $0.5 \mathrm{~g}$ of the sample and treated in a water bath. It was allowed to cool before it was neutralized with few drops of $20 \%$ potassium hydroxide solution. A $10 \mathrm{~mL}$ of equal part of Fehling's solution I and II were added to the mixture and boiled for 5 minutes. A dense brick precipitate indicates the presence of glycosides.

\section{Test for Flavonoids (Ammonium chloride test)}

Ethylacetate $(10 \mathrm{~mL})$ was added to $0.1 \mathrm{~g}$ of the sample and heated in the water bath for 3 minutes. The mixture was cooled and filtered. A $1 \mathrm{ml}$ portion of $1 \%$ aluminum chloride solution was added to $4 \mathrm{ml}$ portion of the filtrate and shaken vigorously. A yellow-color in the aluminum chloride layer indicates the presence of flavonoids.

\section{Test for Saponins (Frothing and Emulsion test)}

A $20 \mathrm{ml}$ volume of distilled water was added to $0.2 \mathrm{~g}$ of the sample and boiled on a water bath for 2 minutes. The mixture was filtered while hot and allowed to cool, and the filtrate was used for the following tests

Frothing test: The filtrate was diluted with $5 \mathrm{~mL}$ of distilled water and shaken vigorously; formation of a stable persistent froth (foam) upon standing indicates the presence of saponins. 
Emulsion test: A few drops of olive oil were added to the froth formed above and shaken vigorously; the formation of emulsion indicates the presence of saponins.

\section{Test for Steroids (Sulphuric acid test)}

An amount of $0.5 \mathrm{~g}$ of the sample was mixed with $2 \mathrm{~mL}$ of acetic anhydride followed by $2 \mathrm{~mL}$ of dilute sulphuric acid. A color change from violet to blue or green indicates the presence of Steroids.

Test for Tannins (Ferric chloride and Lead acetate test)

Distilled water $(20 \mathrm{~mL})$ was added to $0.5 \mathrm{~g}$ of the sample. It was shaken, filtered, and the filtrate was used for the following tests:

Ferric chloride test: A few drops of ferric chloride were added to $3 \mathrm{~mL}$ of the filtrate in a test tube. The formation of a greenish precipitate indicates the presence of tannins.

Lead acetate solution test: A few drops of lead acetate were added to $3 \mathrm{ml}$ of the filtrate. The formation of a reddish color indicates the presence of tannins.

\section{Preparation of Ointments}

Simple ointments containing $1 \% \mathrm{w} / \mathrm{w}$ and $2 \% \mathrm{w} / \mathrm{w}$ of the methanol extract concentrate of both the leaves and stem bark Anthocleista djalonensis were prepared by fusion method, ${ }^{36}$ according to the following formula:

\section{Ingredient per $100 \mathrm{~g}$}

Plant extracts......................................................................

Cetostearyl alcohol......................................................... 5.0

Wool fat..................................................................... $5.0 \mathrm{~g}$

Hard paraffin ................................................................... $5.0 \mathrm{~g}$

White soft paraffin................................................... 85.0

In the above formula, $X$ was used as $1 \mathrm{~g} \%$ and $2 \mathrm{~g} \%$ (10mg and $20 \mathrm{mg}$ ) of the stem bark and leaf extract ointment by mixing ingredients in a mortar with a pestle until smooth ointment was produced. The prepared ointments were stored in a collapsible plastic tube and

Table 1: Treatment regime for the different animal groups

\begin{tabular}{ll}
\hline Group & Treatment \\
\hline 1 & Dermazin (Positive control) \\
2 & Ointment base (Negative control) \\
3 & $1 \%$ Stem bark extract Ointment \\
4 & $2 \%$ Stem bark extract Ointment \\
5 & $1 \%$ leaves extract Ointment \\
6 & $2 \%$ leaves extract Ointment \\
\hline
\end{tabular}

labeled accordingly to be applied to the burn wound site of the animals.

\section{Preparation of wound site (Burn Wound Model)}

The experimental protocols adopted were in accordance with the guidelines stipulated by the institution of the animal ethics committee. The Wistar albino rats were first anesthetized with $100 \mathrm{mg} / \mathrm{kg}: 10 \mathrm{mg} / \mathrm{kg}$ of Ketamine: Xylazine. The hairs of the dorsal region of the rats were shaved with a sterile blade and the burns was created on the shaved area using a cylindrical rod, which is $2 \mathrm{~cm}$ in diameter. The rod was heated until it was red hot before it was then placed on the shaved dorsal area of the animals for about 5 seconds to get a superficial burn, i.e., of partialthickness and the inflicted wound was left undressed.

\section{Treatment Protocol:}

The animals were grouped into six with four animals $(n=4)$ in each group. Measurement was taken before commencement of treatment (i.e., $2 \mathrm{~cm}$ ), and the wound was left untreated for 48 hours to allow bacterial colonization before daily treatment of the wound was started. The wounds were first cleaned using hydrogen peroxide and cotton wool before daily administration of the treatments was done for sixteen (16) days using the different concentration of the crude extract, standard treatment as well as a negative treatment as stated in Table 1 below.

\section{Wound contraction and epithelisation}

The percentage wound contraction was calculated during the wound healing process. After the creation of the wound, the diameter of the wound area was measured with a measuring rule along the circular area of the wound margin on alternate days (every two days interval) by subtracting the unhealed area size from the initial wound size.

$$
\text { Percentage wound contraction }=\frac{\text { Initial wound size }-\begin{array}{c}
\text { wound size on the } \\
\text { day of measurement }
\end{array}}{\text { Initial wound size }} \times 100
$$

\section{Statistical Analysis:}

Data were statistically analyzed by one-way analysis of variance (ANOVA; DUNNET post hoc test), the difference between means of treated and control group were considered significant at $\mathrm{p}<0.05$. All the values were expressed as mean \pm standard error mean (S.E.M).

Table 2: Extraction yields from the leaf and stem bark of Anthocleista djalonensis

\begin{tabular}{llllll}
\hline & Part of plant & $\begin{array}{l}\text { Extraction } \\
\text { solvent }\end{array}$ & $\begin{array}{l}\text { Weight of the } \\
\text { plant material } \\
\text { used }(g)\end{array}$ & $\begin{array}{l}\text { Weight of extract } \\
\text { after drying }(g)\end{array}$ & $\begin{array}{l}\text { Percentage yield } \\
(\%)\end{array}$ \\
\hline Anthocleista djalonensis & Leaves & $95 \%$ methanol & 500 & 36.5 & 7.3 \\
Anthocleista djalonensis & Stem bark & $95 \%$ methanol & 500 & 30.8 & 6.16 \\
\hline
\end{tabular}


Table 3: The phytochemical constituents present in the methanolic extract of leaves and stem bark of Anthocleista djalonensis.

\begin{tabular}{lcccccccc}
\hline Extract used & Alkaloids & Reducing sugar & Glycosides & Flavonoids & Tannins & Saponins & Steroids \\
\hline Leaf extract & - & - & + & + & ++ & + & + \\
\hline Stem bark & - & + & - & + & ++ & + & - \\
\hline
\end{tabular}

+ = present, ++ = highly present, - = absent

\section{DISCUSSION}

From table 2, the percentage yield of leave and stem bark extract obtained were 7.3 and 6.16, respectively. The result of the phytochemical analysis of the leaf extract (Table 3), reveals the presence of glycosides, flavonoids, tannins, saponins, and steroids while that of the stem bark extract revealed the presence of reducing sugar, flavonoids, tannins, and saponins. Tannins were highly present in both the leave and stem bark extract. As polyphenolic compounds, tannins are highly watersoluble in nature thus explaining the reason for greater yield from both plant part after extraction. Medicinally, tannins provide astringent, antioxidant, antiseptic, hemostatic, and toning properties when present in a plant. As a result of these properties, they coagulate the mucosal tissues and proteins, thereby providing a layer that insulates and protects the skin when exposed to pain and irritation. Studies have also reported the preparations from herbs containing tannins are used in treating skin disorders, including scars, burns, wounds e.t.c. It has also been reported that oral ingestion of tannins may be intolerable in certain patients because of its ability to inhibit the absorption of some vitamins

Table 4: Effect of Methanol extract of leaves and stems bark of Anthocleista djalonensis on wound contraction showing percentage

\begin{tabular}{|c|c|c|c|c|c|c|c|c|c|c|}
\hline TREATMENT & & Day 0 & Day 2 & Day 4 & Day 6 & Day 8 & Day 10 & Day 12 & Day 14 & Day 16 \\
\hline \multirow[t]{2}{*}{ DERMAZIN } & $\begin{array}{l}\text { Wound Size } \\
(\mathrm{cm})\end{array}$ & 2.00 & 1.83 & 1.65 & 1.50 & 1.30 & 0.95 & 0.88 & 0.48 & 0.15 \\
\hline & $\begin{array}{l}\% \text { Wound } \\
\text { Contraction }\end{array}$ & 0.00 & 8.50 & 17.50 & 25.00 & 35.00 & 52.50 & 56.00 & 76.00 & 92.5 \\
\hline \multirow[t]{2}{*}{$\begin{array}{l}\text { OINTMENT } \\
\text { BASE }\end{array}$} & $\begin{array}{l}\text { Wound Size } \\
(\mathrm{cm})\end{array}$ & 2.00 & 2.00 & 1.75 & 1.70 & 1.50 & 1.33 & 0.88 & 0.60 & 0.48 \\
\hline & $\begin{array}{l}\% \text { Wound } \\
\text { Contraction }\end{array}$ & 0.00 & 0.00 & 12.50 & 15.00 & 25.00 & 33.50 & 56.00 & 70.00 & 76.00 \\
\hline \multirow{2}{*}{$\begin{array}{l}1 \% \text { STEM } \\
\text { BARK } \\
\text { EXTRACT }\end{array}$} & $\begin{array}{l}\text { Wound Size } \\
(\mathrm{cm})\end{array}$ & 2.00 & 1.68 & 1.58 & 1.55 & 1.35 & 1.15 & 1.05 & 0.60 & 0.35 \\
\hline & $\begin{array}{l}\% \text { Wound } \\
\text { Contraction }\end{array}$ & 0.00 & 16.00 & 21.00 & 22.50 & 32.50 & 42.50 & 47.50 & 70.00 & 82.50 \\
\hline \multirow{2}{*}{$\begin{array}{l}2 \% \text { STEM } \\
\text { BARK } \\
\text { EXTRACT }\end{array}$} & $\begin{array}{l}\text { Wound Size } \\
(\mathrm{cm})\end{array}$ & 2.00 & 1.70 & 1.65 & 1.43 & 1.15 & 0.90 & 0.80 & 0.45 & 0.25 \\
\hline & $\begin{array}{l}\% \text { Wound } \\
\text { Contraction }\end{array}$ & 0.00 & 15.00 & 17.50 & 28.50 & 42.50 & 55.00 & 60.00 & 77.50 & 87.50 \\
\hline \multirow[t]{2}{*}{$\begin{array}{l}1 \% \text { LEAF } \\
\text { EXTRACT }\end{array}$} & $\begin{array}{l}\text { Wound Size } \\
(\mathrm{cm})\end{array}$ & 2.00 & 1.80 & 1.73 & 1.55 & 1.33 & 1.20 & 0.77 & 0.40 & 0.37 \\
\hline & $\begin{array}{l}\% \text { Wound } \\
\text { Contraction }\end{array}$ & 0.00 & 10.00 & 13.50 & 22.50 & 33.50 & 40.00 & 61.50 & 80.00 & 81.50 \\
\hline \multirow[t]{2}{*}{$\begin{array}{l}2 \% \text { LEAF } \\
\text { EXTRACT }\end{array}$} & $\begin{array}{l}\text { Wound size } \\
(\mathrm{cm})\end{array}$ & 2.00 & 1.88 & 1.70 & 1.55 & 1.35 & 1.00 & 0.70 & 0.45 & 0.25 \\
\hline & $\begin{array}{l}\text { \% Wound } \\
\text { Contraction }\end{array}$ & 0.00 & 6.00 & 15.00 & 22.50 & 32.50 & 50.00 & 65.00 & 77.50 & 87.50 \\
\hline
\end{tabular}




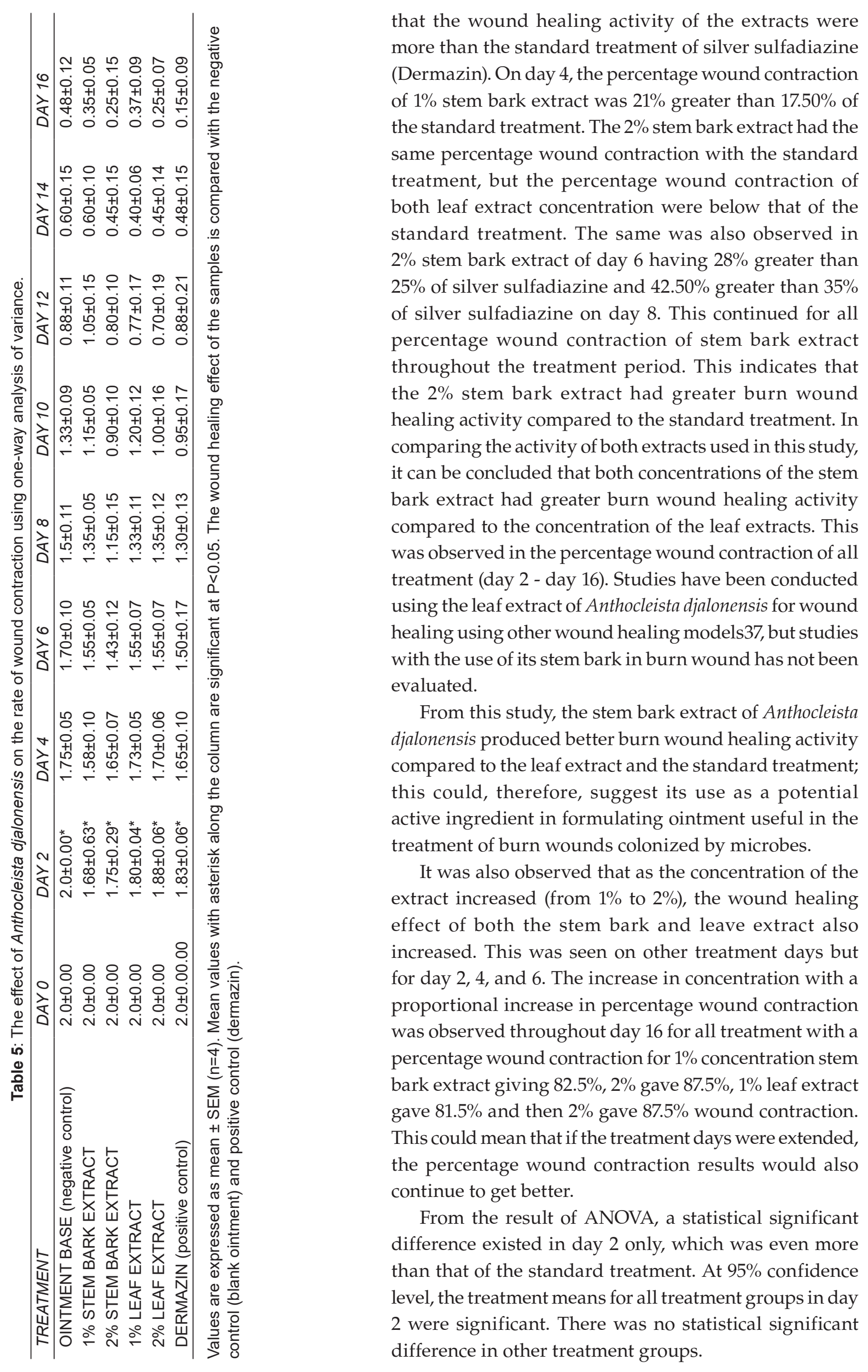




\section{CONCLUSION}

In conclusion, the present study experimentally demonstrates the effective burn wound healing activity of both the leaves and the stem bark of Anthocleista djalonensis extract. It contains bioactive phytochemical constituents which has burn wound healing activity on the colonized burn wound. Leaving a burn wound unattended to for 48hours exposes it to microbial colonization. Its activity increased with increased concentrations of the extracts, and the stem bark showed better activity when compared with the leaf extract and even greater activity compared to the standard burn ointment. Therefore, the stem bark extract of Anthocleista djalonensis could be a potential active ingredient in formulations intended for the treatment of burn wound. However, scar remodeling is an important aspect of burn wound healing, but regrettably, this study has not covered it. Further studies could be conducted to evaluate the scar remodeling effect of this plant extract.

\section{REFERENCES}

1. Sunil S. Jalalpure, Nitin Agrawal, M.B. Patil, R. Chimkode, Ashish Tripathi. Antimicrobial and wound healing activities of leaves of Alternanthera sessilis Linn. International Journal of Green Pharmacy. 2008

2. Anyanwu, M.U., Okoye, R.C. Antimicrobial activity of Nigerian medicinal plants. J. Intercult Ethnopharmacol.2017;6(2): 240-259.

3. Agyare C, Bekoe E.O, Boakye Y.D, et al. Medicinal Plants and Natural Products with Demonstrated Wound Healing Properties. INTECHOPEN BOOKS. A chapter from the book Wound healing new insight into Ancient challenges. Downloaded from: http://www.intechopen.com/books/ wound-healing-new-insightsinto-ancient-challenges. 2016.

4. Somboonwong J, Kankaisre M, Tantisira B et al. Wound healing activities of different extracts of Centella asiatica in incision and burn wound models: an experimental animal study. The official journal of the International Society for Complementary Medicine Research (ISCMR). 2012; 12:103.

5. MayoClinicStaff:Burns http://www.mayoclinic.com/health/ burns/DSO1176/METHODS=printaccessed Dec.2011.

6. World Health Organization: Regional News https://www. who.int/news-room/fact-sheets/detail/burns. accessed $6^{\text {th }}$ March 2018.

7. Patel A.M, Kurbetti S.M, Savadi R.V, et al. Preparation and Evaluation of Wound Healing Activity of New Polyherbal Formulations in Rats. American Journal of Phytomedicine and Clinical Therapeutics. 2013; 1(6):498-506.

8. William C. Shiel Jr., MD, FACP, FACR . FIRST AID FOR BURNS CENTER. Reviewed on 12/21/2018.

9. Rowan M.P, Cancio L.C, Elster E.A, et al. Burn wound healing and treatment: review and advancements. Crit Care. 2015; 19:243.

10. Sen S, Palmieri T, Greenhalgh D. Review of burn research for the year 2013. J Burn Care Res. 2013; 35:362-8.

11. WORLD REPORT ON CHILD INJURY PREVENTION: Chapter 4, pages $79-98$
12. DEVELOPMENT OF HEALTH AND HUMAN SERVICE-USA. CENTRE FOR DISEASE CONTROL; INJURY PREVENTION.

13. https://www.cdc.gov/masstrauma/factsheets/public/burns. pdf

14. American Burn Association Burn Incidence Fact Sheet: Burn Incidence and Treatment in the United States 2016.

15. Coban Y.K. Infection control in severely burned patients. World J Crit Care Med. 2012; 1:94-101.

16. Tsiouris C.G and Tsiouri M.G. Human microflora, probiotics and wound healing. Wound Medicine 2017; 19:33-38.

17. D'Avignon L.C, Chung K.K, Saffle J.R, et al. Prevention of Combat-Related Infections Guidelines Panel. Prevention of infections associated with combat-related burn injuries. J Trauma. 2011; 71:S282-9.

18. Selvaraj N, Lakshmanan B, Mazumder P.M et al. Evaluation of wound healing and antimicrobial potentials of Ixora coccinea root extract. Asian Pacific Journal of Tropical Medicine. 2011; 4(12):959-63.

19. Azzopardi E.A, Azzopardi E, Camiller L, et al. Gram Negative Wound Infection in Hospitalised Adult Burn PatientsSystematic Review and Metanalysis. PLoS One. 2014; 9(4): e95042.

20. Huang G, Liang B, Liu G, et al. Low Dose of Glucocorticoid Decreases the Incidence of Complications in Severely Burned Patients by Attenuating Systemic Inflammation. J Crit Care. 2015; 30: 436

21. D'Avignon L.C, Hogan B.K, Murray C.K, et al. Contribution of bacterial and viral infections to attributable mortality in patients with severe burns: an autopsy series. Burns 2010; 36: 773-779.

22. Tiwari V.K. Burn wound: how it differs from other wounds? Indian J Plast Surg. 2012; 45:364-73. doi: 10.4103/0970-0358. 101319.

23. Garcia-Espinoza JA, Aguilar-Aragon VB, Ortiz-Villalobos EH, et al. Burns: Definition, Classification, Pathophysiology and Initial Approach. Gen Med (Los Angeles) 2017; 5: 298. doi:10.4172/2327-5146.1000298.

24. Foncerrada G, Capek K.D, Herndon D.N, et al. The state of the Art on Burn Wound Healing 2017.

25. Branski L.K, Al-Mousawi A, Rivero H, et al. Emerging infections in burns. Surg Infect 2009; 10:389-97. doi: 10.1089/ sur.2009.024.

26. Ajibesin K.K, Bala D, N and Umoh U.F. Ethno medicinal survey of plants used by the indigenes of Rivers State of Nigeria. Journal Pharmaceutical Biology 2012; 50(9) Pages 1123-1143. https://doi.org/10.3109/13880209.2012.661740.

27. Sivamani R.K, Ma B.R, Wehrli L.N et al. Phytochemicals and Naturally Derived Substances for Wound Healing. Adv Wound Care (New Rochelle), 2012; 1(5): 213-217.

28. Singh A, Singh P, Singh G et al Plant used in primary health practices in Vindhya region of eastern Uttar Pradesh, India. International Journal of Herbal Medicine 2014;2:31-37.

29. Saini S, Dhiman A and Nanda S. Traditional indian medicinal plants with potential wound healing activity: A review. International journal of pharmaceutical sciences and research. 2017; 0975-8232,

30. van Koppen C.J and Hartmann R.W. Advances in the treatment of chronic wounds: a patent review. Expert Opin Ther Pat. 2015; 25:931-937.

31. Hosseinkhani A, Falahatzadeh M, Raoofi E, et al. An Evidence-Based Review on Wound Healing Herbal Remedies from Reports of Traditional Persian Medicine. J Evid Based 
Complementary Altern Med. 2017; 22(2): 334-343 https:// dx.doi.org/10.1177\%2F2156587216654773.

32. Anyanwu G.O, Nisar-ur-Rehman, Onyeneke C.E, et al. Medicinal plants of the genus Anthocleista-A review of their ethnobotany, phytochemistry and pharmacology. J Ethnopharmacol. 2015; 175:648-67. doi: 10.1016/j.jep.2015.09.032.

33. Shorinwa O.A, Enemuoh A.O , and Uche F.I. Anti-inflammatory and analgesic activities of methanol extracts of stem bark of Anthocleista djalonensis in wistar rats. Journal of Applied Pharmaceutical Science. 2015; 5 (11), pp. 117-120.

34. Anyanwu, G.O, Onyeneke, E.C, Usunobun, U., et al. Impact of Anthocleista vogelii root bark ethanolic extract on weight reduction in high carbohydrate diet induced obesity in male wistar rats. Afr. J. Biochem. Res. 2013; 7, 225-232.

35. Ojiako E. N. and Okoye I. E. Phytochemical studies and antimicrobial activity of Anthocleista djalonensis (Okpokolo leaf) Journal of Chemical and Pharmaceutical Research, 2015; 7(5):70-72.
36. HARBORNE J.B (1998) Phytochemical Methods A Guide to Modern Techniques of Plant Analysis. doi: 10.1007/97894-009-5921-7. Trease, G. E. and Evans, W. C. (2002). Phytochemicals. In: Pharmacognosy, Saunders Publishers, London, 2002.

37. Shelke Usha Y. and Mahajan Ashish A. Review on: an Ointment. International Journal of Pharmacy and Pharmaceutical Research. 2015; 4 (2): 170-192.

38. Akinyemi A.I. and Ogundare. A. Antibacterial Properties of the Leaf Extracts of Anthocleista djalonensis A. Chev on Some Pathogenic Organisms. European Journal of Medicinal Plants. 2014; 4(1): 75-85.

39. Panche, A. N., Diwan, A. D., and Chandra S. R. Flavonoids: an overview. J Nutr Sci. 2016; 5: e47. doi: 10.1017/jns.2016.41.

40. Liwa A.C, Barton E.N, Cole W.C, et al. Bioactive Plant Molecules, Sources and Mechanism of Action in the Treatment of Cardiovascular Disease. Pharmacognosy Fundamentals, Applications and Strategies 2017; Pages 315-336. 